\title{
Article \\ The Glass Ceiling in the Sport Industry: Spanish Version of the Women as Managers Scale (WAMS)
}

\author{
Jana Gallardo-Pérez $^{1}\left(\mathbb{D}\right.$, Blanca Romero-Moraleda ${ }^{2}$, Víctor Paredes-Hernández ${ }^{3}$ and Jairo León-Quismondo ${ }^{4, * \mathbb{C}}$ \\ 1 Department of Didactics of Physical Education and Health, Faculty of Education, Universidad Internacional \\ de la Rioja-UNIR, Avenida de la Paz, 137, Logroño, 26006 La Rioja, Spain; janagp8@gmail.com \\ 2 Department of Physical Education, Sport and Human Movement, Universidad Autónoma de Madrid, \\ 28049 Madrid, Spain; blanca.romero@uam.es \\ 3 Department of Sport Sciences, Faculty of Health, Universidad Camilo José Cela, Calle Castillo de Alarcón, \\ 49, Villanueva de la Cañada, 28692 Madrid, Spain; vparedes@ucjc.edu \\ 4 Faculty of Sport Sciences, Universidad Europea de Madrid, Calle Tajo s/n, Villaviciosa de Odón, \\ 28670 Madrid, Spain \\ * Correspondence: jairo.leon@universidadeuropea.es; Tel.: +34-912-113-505
}

check for updates

Citation: Gallardo-Pérez, J.;

Romero-Moraleda, B.;

Paredes-Hernández, V.;

León-Quismondo, J. The Glass

Ceiling in the Sport Industry: Spanish Version of the Women as Managers

Scale (WAMS). Sexes 2021, 2, 163-173.

https://doi.org/10.3390/sexes2020014

Academic Editor: Jean-Nicolas Volff

Received: 28 February 2021

Accepted: 12 April 2021

Published: 15 April 2021

Publisher's Note: MDPI stays neutral with regard to jurisdictional claims in published maps and institutional affiliations.

Copyright: (C) 2021 by the authors. Licensee MDPI, Basel, Switzerland. This article is an open access article distributed under the terms and conditions of the Creative Commons Attribution (CC BY) license (https:// creativecommons.org/licenses/by/ $4.0 /)$.

\begin{abstract}
The pace of women's access to leadership positions is very different from country to country. With 69.4 out of 100 points, Spain ranks fourth in the European Union (EU) on social power, first measured in the 2020 edition of the Gender Equality Index. However, a need of deepening the reasons for gender inequalities remains. The Women As Managers Scale (WAMS) is a useful tool that allows for the measurement of the attitudinal factors that hinder access to managerial positions. The aim of this study was to validate the Spanish version of the WAMS among sport managers through three factors: acceptance of women in key positions, features for business success, and barriers to access to managerial positions. For that purpose, a questionnaire-as is the original WAMS-was distributed to 401 managers working within sports organizations in the community of Madrid, Spain. Interclass correlation coefficient (ICC) and Student's test were performed to analyze the stability of the scores. The internal consistency of the scales was assessed through Cronbach's alpha, the Homogeneity Index, and Discriminability Index. The construct validity was completed through exploratory factor analysis using principal components. The results show that the WAMS serves as a reference for use as a measure of attitudinal factors that hinder access to an executive position. Therefore, this work generates an instrument with adequate properties in the Spanish context.
\end{abstract}

Keywords: gender; validation; management; leadership; barriers; glass ceiling

\section{Introduction}

Occupational segregation by gender still remains in the labor market, according to previous research [1,2]. The term 'glass ceiling' was first used in 1984 by Gay Bryant in an article in Adweek [3]. Later in March 1986, the term was coined and popularized in a special report by Carol Hymowitz and Timothy D. Schellhardt in The Wall Street Journal [3]. The term is commonly defined as the invisible barriers that prevent women from progressing and gaining entry to higher management in corporations [4]. This metaphor is commonly associated with the gender gap that symbolizes the difficulties that women experience in terms of representation at different enterprise levels [5]. However, it can also be generalized to racial and ethical contexts (i.e., within minorities) [6].

Among legislators and administrators, women are a minority in all European Union countries, ranging on average between $20 \%$ and $30 \%$, or even less such as in Italy, where women comprise only 15\% [7]. Following López-lbor et al. [8], 66\% of the positions are planned only for men. According to the first Occupational Structure Survey of Sport in Spain [9], the number of jobs in 1991 related to managerial or technical sports facilities was 1014. A decade later, in 2001, the estimated number of jobs was 1420. In 2020 in Spain, 
about $43 \%$ of companies have a woman in their team $[10,11]$. However, this percentage decreases as the size of the company increases [10-12]. Currently, Spain is the fourth country in the Gender Equality Index on social power, with 69.4 out of 100 points [13]. Specifically in the sports field, a similar situation occurs. For instance, in Europe, only one out of five employee elite coaches and $8 \%$ of the presidents in national Olympic sports federations are women. Furthermore, $31 \%$ of the members of sports clubs or federations are women [14]. In Spain, the data show that only $20 \%$ of women hold leadership positions in Spanish sports federations [15].

To explain the low levels of representation of women, different types of explanations are provided in the literature. According to Selva et al. [1], three hypotheses explain this situation. The first hypothesis suggests that women have traditionally had less experience in executive positions compared to men [16], reflecting the possible traditional difficulties of accessing education by women because of the pipeline problem. This analogy reflects the situation in which many organizations continue losing female talent $[1,2]$. The leak is explained by examining the level of participation of women in leadership positions. Although it is difficult to measure due to a lack of uniform definitions, current estimates of the number of women in senior positions indicate a very low percentage of those functions [17]. The second hypothesis states that some women are not motivated or have no interest in accessing management positions for personal and family ties [18]. Family responsibilities and household are traditionally associated with women. Consequently, some women respond to this by deciding not to marry or have children, or trying to excel in all aspects by accepting part-time jobs [5]. The third states that some women reject the aforementioned positions also influenced by social constraints [1]. Traditional differences related to academic training received by women that still remain explain this situation. As a result of these and other factors, women are not well represented in decision-making positions or management levels and, therefore, they tend to earn lower wages. They are also at the bottom of the hierarchy in all sectors. For instance, in public administration, women represent about $40 \%$ of the workforce but only hold on average $10 \%$ of management positions, and the highest levels are even less represented.

There are many scales for the study of the glass ceiling and its consequences $[19,20]$. For example, Karaca [21] developed a 38-item scale with seven dimensions for measuring attitudes toward women's promotion or access to managerial positions. Another example is the Multidimensional Aversion to Women Who Work Scale (MAWWWS), which consists of 10 items [22]. With such diverse scales, the comparison between them is complicated because none measure the same gender factors and they are not carried out within the sports field. One of the most widely extended scales for measuring attitudes of people toward women in management is the Women As Managers Scale (WAMS), originally developed by Peters et al. [23]. It measures the general acceptance of women as managers, the necessary features for business success, and the specific barriers toward women. Previous research has applied the WAMS in different populations such in the USA. For instance, Terborg et al. [24] researched a sample of 345 male and 196 female students in the final year of their management course that showed that the WAMS was useful and not limited by factors. Indeed, some authors have also evinced some limitations, mainly related to the instability of the factors within different population samples $[25,26]$, resulting in the unidimensional usage of the scale, instead of the division by factors.

To illustrate the reliability of the scale factors, we use the example of the WAMS article by Cordano et al. [26]. In that study, the authors performed factor analyses of the WAMS by using factor comparisons using the coefficient of congruence. Cordano et al. [26] obtained three factors. The first factor, acceptance of women in key leadership positions, was obtained with moderately high similarity $(\Phi \mathrm{I}, \mathrm{II}=0.95 ; \Phi \mathrm{I}, \mathrm{III}=0.88 ; \Phi \mathrm{II}, \mathrm{II}=0.93)$ as well as being significant $(p<0.05)$ in all scores, with a Cronbach's alpha value of 0.83 . The second factor is called features for business success, and also showed a high coefficient of congruence $(\Phi \mathrm{I}, \mathrm{II}=0.71 ; \Phi \mathrm{I}, \mathrm{III}=0.58 ; \Phi \mathrm{II}, \mathrm{III}=0.39$ ), although only the highest coefficient was significant, with a Cronbach's alpha of 0.75 . Finally, the factor known as specific 
barriers to women's access to a key position produced low coefficients $(\Phi \mathrm{I}, \mathrm{II}=-0.11 ; \Phi \mathrm{I}$, $\mathrm{III}=0.11 ; \Phi \mathrm{II}, \mathrm{III}=-0.50$ ) and none of them were significant, as the Cronbach's alpha coefficient had a low value of 0.46 .

Further research is essential for applying the WAMS in different contexts and in different sectors. The sports industry is one of the most significant emerging markets of the last decades. In order to complement previous work with the data in the sports sector, specific tools for explaining the gender differences in the sports sector are required. To fill this gap in the literature, this paper aims to validate the Women As Managers Scale (WAMS) in the Spanish context, focusing on the sports industry. While it is a widely used tool in the literature, it has not yet been extended in the sports scope nor the Spanish context.

\section{Materials and Methods}

\subsection{Design and Participants}

An observational cross-sectional study was conducted. The sample was composed of 401 sport managers, $50.12 \%$ men $(n=201)$ and $49.88 \%$ women $(n=200)$, with an average age of $43 \pm 10.51$ years for men and $41 \pm 9.43$ years for women. All of them were mainly responsible for the sport center they were leading at that moment. All of them worked in sports organizations located in the community of Madrid, Spain.

Three different positions were considered, according to three hierarchy levels: manager, technical director, and coordinator. Additionally, different types of sport facilities were included with 232 private centers and 169 public organizations.

\subsection{Instrument}

A questionnaire divided into two sections was applied. The first section targeted the sociodemographic characteristics of the sample. The second section measured different attitudes of people toward women in management and was the Women As Managers Scale (WAMS) [16].

The WAMS includes features for success within organizations such as leadership as well as features, stereotypes, and barriers to successful integration into positions such as family responsibilities. The WAMS scale consisted of 21 items divided into three factors (Table 1):

- Acceptance of women in key leadership positions;

- Enterprise features for business success; and

- Specific barriers to access to managerial positions.

Every item was measured on a 7-point Likert scale $(1=$ strongly disagree; $7=$ strongly agree), with 10 of them reverse coded.

The translation was done by a professional Spanish translator, who was fluent in both languages (Spanish and English) so that there were no cultural differences. Appendix A includes the Spanish WAMS.

\subsection{Procedure}

The selection sample was carried out through simple random sampling from the Census of Sports Facilities of the Community of Madrid (2005) [27]. Later, one person for each sports entity was selected. In each organization, a simple proportional assignment was made according to gender, that is, assigning in each type of entity, $50 \%$ of interviews with women and $50 \%$ of interviews with men.

Personal interviews were conducted individually and face-to-face (time of interview 15 min per person) with the 401 participants. This type of interview provides a high degree of response rate and increases the reliability of the research [28]. To measure the stability of the responses of the questionnaire, within 15-30 days, the participants were contacted via email (voluntarily provided previously) with an invitation for a second individual and face-to-face questionnaire, obtaining a response rate of $10 \%$ of the total sample $(n=40)$. 
Table 1. Women As Managers Scale (WAMS) [24].

\begin{tabular}{|c|c|c|}
\hline & WAMS Questionnaire & Factors \\
\hline 1. & It is less desirable for women than men to have a job that requires responsibility * & 3 \\
\hline 2. & Women have the objectivity required to evaluate business situations properly & 3 \\
\hline 3. & Challenging work is more important to men than it is to women * & 3 \\
\hline 4. & Men and women should be given equal opportunity for participation in management training programs & 1 \\
\hline 5. & Women can acquire the necessary skills to be successful managers & 1 \\
\hline 6. & $\begin{array}{l}\text { On average, women managers are less capable of contributing to an organization's overall goals than are } \\
\text { men * }\end{array}$ & 2 \\
\hline 7. & It is not acceptable for women to assume leadership roles as often as men * & 2 \\
\hline 8. & The business community should someday accept women in key managerial positions & 1 \\
\hline 9. & Society should regard work by female managers as valuable as work by male managers & 2 \\
\hline 10. & It is acceptable for women to compete with men for top executive positions & 1 \\
\hline 11. & The possibility of pregnancy does not make women less desirable employees than men & 3 \\
\hline 12. & Women would no more allow their emotions to influence their managerial behavior than would men & 3 \\
\hline 13. & Problems associated with menstruation should not make women less desirable than men as employees & 3 \\
\hline 14. & To be a successful executive, a woman does not have to sacrifice some of her femininity & 3 \\
\hline 15. & $\begin{array}{l}\text { On average, a woman who stays at home all the time with her children is a better mother than a woman who } \\
\text { works outside the home at least half time* }\end{array}$ & 3 \\
\hline 16. & Women are less capable of learning mathematical and mechanical skills than men * & 2 \\
\hline 17. & Women are not ambitious enough to be successful in the business world * & 2 \\
\hline 18. & Women cannot be assertive in business situations that demand it * & 2 \\
\hline 19. & Women possess the self-confidence required of a good leader & 2 \\
\hline 20. & Women are not competitive enough to be successful in the business world * & 2 \\
\hline 21. & Women cannot be aggressive in the business situations that demand it * & 2 \\
\hline
\end{tabular}

\section{Factors}

Factor 1: Acceptance of women in key positions

Factor 2: Enterprise features for business success

Factor 3: Specific barriers for access to managerial positions

Note: * Reverse coded.

Informed consent was obtained from all participants. All were informed of the objective of the study. All declared to be adults (over 18 years old) and agreed to have been satisfactorily informed and to have fully understood the information provided. Their questions were answered throughout the process and they agreed to voluntarily fill out the questionnaire. They agreed that their data would be confidentially used.

\subsection{Data Analysis}

Based on the theoretical framework on the objectives of the research as well as following the directions for the analysis of survey data of previous work $[28,29]$, the analysis was performed with IBM SPSS 23.0 Statistics software (IBM Inc., Chicago, IL, USA), setting the critical level of significance at $p<0.05$.

The descriptive data are described as mean, standard deviation, and percentages. To analyze the stability of the scores, the intraclass correlation coefficient (ICC) was used. The Student's t-test was also conducted to compare scores of test-retest.

The internal consistency of the scales was assessed using the Cronbach's alpha, Homogeneity Index, and Discriminability Index, thus obtaining the correlations of the items with the total score of the scale and standard deviation of the items. 
An exploratory factor analysis using principal components was also applied to the analysis of the construct validity of the WAMS scale.

\section{Results}

\subsection{Descriptive Statistics}

Table 2 shows the descriptive data from the study sample. Male and female participants were included in the sample from public and private organizations. Additionally, three types of jobs were considered: manager, technical director, and coordinator.

Table 2. Study sample.

\begin{tabular}{cccc}
\hline Descriptive Statistics & Men & Women & Total \\
\hline Gender & 201 & 200 & 401 \\
Public organizations & 94 & 75 & 169 \\
Private organizations & 107 & 125 & 232 \\
Type of job: Manager & 111 & 77 & 189 \\
Type of job: Technical Director & 38 & 66 & 104 \\
Type of job: Coordinator & 52 & 57 & 109 \\
\hline
\end{tabular}

\subsection{Stability of Scores}

The coefficient of correlation for WAMS full-scale including the 21 items was 0.677 . After analyzing the stability of scores on the different factors, an intraclass correlation coefficient of 0.362 was obtained for the first factor, 0.86 for the second factor, and 0.474 for the third factor.

Finally, the total scores on the scale in the retest $(81.40 \pm 8.47)$ were not significantly different from those obtained in the initial test $(82.56 \pm 08.09 ; \mathrm{t} 42=1.06, p>0.05)$.

Table 3 shows the results obtained in the test and the retest of each of the WAMS factors. No significant differences were detected between these scores and the acceptance factor $(\mathrm{t} 42=1.13)$, nor the features factor $(\mathrm{t} 42=1.68)$, nor the barriers factor $(\mathrm{t} 42=6.71)$.

Table 3. Descriptive statistics for the test-retest.

\begin{tabular}{ccccc}
\hline \multirow{2}{*}{ Factors } & \multicolumn{2}{c}{ Test } & \multicolumn{2}{c}{ Re-Test } \\
\cline { 2 - 5 } & $\mathbf{M}$ & SD & M & SD \\
\hline Acceptance & 6.75 & 0.45 & 6.83 & 0.26 \\
Features & 6.40 & 0.64 & 6.52 & 0.64 \\
Barriers & 4.97 & 0.67 & 5.70 & 6.75 \\
\hline Note: $\mathrm{M}=$ mean; SD $=$ standard deviation. Scores on a 7-point Likert scale $(1=$ strongly disagree; $7=$ strongly agree $)$
\end{tabular}

\subsection{Reliability}

The analysis of the internal consistency of the full scale revealed a Cronbach's alpha coefficient of 0.752. Analysis of internal consistency for the three factors of the WAMS showed the following results: 0.79 for the acceptance factor, 0.77 for the features factor, and finally, for the barriers factor, it was 0.34 .

As shown in Table 4, the correlations between the items and the total score scale revealed a high degree of homogeneity, since most of the items presented correlations with a total scale score greater than 0.30 and on the other hand, the internal consistency of the scale $(0.752)$ could be increased only with the elimination of items 11 and 12 . 
Table 4. Mean and standard deviation of each item considering full-scale items with total scale correlation after the elimination of items and Cronbach's alpha if the item is deleted.

\begin{tabular}{ccccc}
\hline Item & M & SD & $\begin{array}{c}\text { Adjusted Item-Scale } \\
\text { Correlation }\end{array}$ & $\begin{array}{c}\text { Cronbach's Alpha If the Item } \\
\text { Is Eliminated }\end{array}$ \\
\hline Item 1 & 6.42 & 1.27 & 0.409 & 0.736 \\
Item 2 & 6.36 & 1.11 & 0.224 & 0.748 \\
Item 3 & 6.22 & 1.45 & 0.436 & 0.733 \\
Item 4 & 6.82 & 0.82 & 0.484 & 0.737 \\
Item 5 & 6.70 & 0.82 & 0.511 & 0.736 \\
Item 6 & 6.67 & 0.92 & 0.508 & 0.734 \\
Item 7 & 6.44 & 1.20 & 0.398 & 0.737 \\
Item 8 & 6.70 & 0.78 & 0.492 & 0.737 \\
Item 9 & 6.76 & 0.83 & 0.457 & 0.738 \\
Item 10 & 6.49 & 1.14 & 0.362 & 0.740 \\
Item 11 & 3.01 & 2.26 & 0.041 & 0.788 \\
Item 12 & 4.61 & 2.29 & 0.011 & 0.785 \\
Item 13 & 6.15 & 1.73 & 0.216 & 0.752 \\
Item 14 & 6.08 & 1.64 & 0.215 & 0.751 \\
Item 15 & 6.21 & 1.38 & 0.376 & 0.738 \\
Item 16 & 6.31 & 1.31 & 0.342 & 0.740 \\
Item 17 & 6.26 & 1.43 & 0.381 & 0.737 \\
Item 18 & 6.57 & 1.04 & 0.528 & 0.731 \\
Item 19 & 6.42 & 1.07 & 0.473 & 0.734 \\
Item 20 & 6.29 & 1.41 & 0.466 & 0.731 \\
Item 21 & 6.39 & 1.26 & 0.481 & 0.731 \\
\hline
\end{tabular}

Note: $\mathrm{M}$ = mean; $\mathrm{SD}$ = standard deviation. Scores on a 7-point Likert scale (1 = strongly disagree; 7 = strongly agree)

When performing an analysis of items considering the three factors that make the WAMS, it appears that the acceptance factor items show a high degree of correlation with the total scale, and only the removal of item 10 increased the internal consistency of this factor (Table 5).

Table 5. Statistical total-item: Acceptance.

\begin{tabular}{ccccc}
\hline Item & M & SD & $\begin{array}{c}\text { Adjusted Item-Scale } \\
\text { Correlation }\end{array}$ & $\begin{array}{c}\text { Cronbach's Alpha If the Item } \\
\text { Is Eliminated }\end{array}$ \\
\hline Item 4 & 6.82 & 0.82 & 0.658 & 0.729 \\
Item 5 & 6.70 & 0.82 & 0.553 & 0.761 \\
Item 8 & 6.70 & 0.78 & 0.671 & 0.728 \\
Item 9 & 6.76 & 0.83 & 0.666 & 0.726 \\
Item 10 & 6.49 & 1.14 & 0.415 & 0.829 \\
\hline
\end{tabular}

Note: $\mathrm{M}$ = mean; $\mathrm{SD}$ = standard deviation. Scores on a 7-point Likert scale (1 = strongly disagree; 7 = strongly agree)

Regarding the features factor of the WAMS, there was a high degree of homogeneity among items, with correlations higher than 0.30 . Furthermore, the internal consistency of the scale would increase if any item were deleted (Table 6).

Finally, the barriers factor had a low degree of homogeneity among numerous items with correlations less than 0.20 . Furthermore, the standard deviations showed little discriminatory power of the items. Thus, the removal of any of the items increased the internal consistency of the scale (Table 7). 
Table 6. Statistical total-item: Features.

\begin{tabular}{ccccc}
\hline Item & M & SD & $\begin{array}{c}\text { Adjusted Item-Scale } \\
\text { Correlation }\end{array}$ & $\begin{array}{c}\text { Cronbach's Alpha If the Item } \\
\text { Is Eliminated }\end{array}$ \\
\hline Item 6 & 6.67 & 0.92 & 0.510 & 0.754 \\
Item 7 & 6.44 & 1.20 & 0.394 & 0.768 \\
Item 16 & 6.31 & 1.31 & 0.363 & 0.775 \\
Item 17 & 6.26 & 1.43 & 0.461 & 0.760 \\
Item 18 & 6.57 & 1.04 & 0.639 & 0.732 \\
Item 19 & 6.42 & 1.07 & 0.446 & 0.760 \\
Item 20 & 6.29 & 1.41 & 0.541 & 0.744 \\
Item 21 & 6.39 & 1.26 & 0.566 & 0.739 \\
\hline Note: M = mean; SD = standard deviation. Scores on a 7-point Likert scale (1 = strongly disagree; 7 = strongly agree).
\end{tabular}

Table 7. Statistical total-item: Barriers.

\begin{tabular}{ccccc}
\hline Item & M & SD & $\begin{array}{c}\text { Adjusted Item-Scale } \\
\text { Correlation }\end{array}$ & $\begin{array}{c}\text { Cronbach's Alpha If the Item } \\
\text { Is Eliminated }\end{array}$ \\
\hline Item 1 & 6.42 & 1.27 & 0.162 & 0.307 \\
Item 2 & 6.36 & 1.11 & 0.109 & 0.328 \\
Item 3 & 6.22 & 1.45 & 0.234 & 0.270 \\
Item 11 & 3.01 & 2.26 & 0.024 & 0.399 \\
Item 12 & 4.61 & 2.29 & 0.064 & 0.374 \\
Item 13 & 6.15 & 1.73 & 0.251 & 0.251 \\
Item 14 & 6.08 & 1.64 & 0.161 & 0.302 \\
Item 15 & 6.21 & 1.38 & 0.232 & 0.274 \\
\hline Note: M = mean; SD = standard deviation. Scores on a 7-point Likert scale (1 = strongly disagree; 7 = strongly agree).
\end{tabular}

To explore the construct validity of the scale, an exploratory factor analysis using principal components and varimax rotation was conducted. Both the index Kaiser-MeyerOlkin (0.855) and Bartlett's test of sphericity (c2 = 2152,446, gl = 210, $p<0.001)$, demonstrated the suitability of the matrix for analysis. The analysis returned three factors, which together accounted for $40.66 \%$ of the variance.

Factor 1 (acceptance) grouped items 2, 4, 5, 8, 9, and 10, and explained $8.88 \%$ of the variance, factor 2 (features) grouped items 1, 3, 6, 7, 15, 16, 17, 18, 19, 20, and 21 and explained $25.64 \%$, and factor 3 (barriers) grouped items $11,12,13$, and 14, explaining $6.15 \%$ of the variance (Table 8 ).

Factor analysis does not reproduce the theoretical structure of the scale, since factor 1 contains an item of the factor barriers (item 2) and factor 2 contains three items of factor barriers (items 1, 3, and 15). This may have occurred because both item 1 (It is less desirable for women than for men to have a job that requires responsibility), item 3 (The challenges in the workplace are more important for men than for women), and item 15 (On average, a woman who stays at home all the time to care for their children is a better parent than having a job outside the home, even part-time), can be seen as features, characteristics, expectations, and virtues that women may have to achieve success at work, which is what we called factor 2. Item 2 (Women have the objectivity required to evaluate business situations) can be understood as a condition to be considered for acceptance of women in business situations (factor 1), rather than as a barrier to access or promotion to a business (factor 3). 
Table 8. Rotated components matrix.

\begin{tabular}{|c|c|c|c|}
\hline \multirow{2}{*}{ Items } & \multicolumn{3}{|c|}{ Factorial Analysis with Varimax Rotation $(N=401)$} \\
\hline & $\begin{array}{c}\text { Factor } 1 \\
\text { Acceptance }\end{array}$ & $\begin{array}{l}\text { Factor } 2 \\
\text { Features }\end{array}$ & $\begin{array}{l}\text { Factor } 3 \\
\text { Barriers }\end{array}$ \\
\hline Item 2 & 0.38 & & \\
\hline Item 4 & 0.76 & & \\
\hline Item 5 & 0.71 & & \\
\hline Item 8 & 0.79 & & \\
\hline Item 9 & 0.80 & & \\
\hline Item 10 & 0.50 & & \\
\hline Item 1 & & 0.60 & \\
\hline Item 3 & & 0.56 & \\
\hline Item 6 & & 0.54 & \\
\hline Item 7 & & 0.48 & \\
\hline Item 15 & & 0.35 & \\
\hline Item 16 & & 0.43 & \\
\hline Item 17 & & 0.64 & \\
\hline Item 18 & & 0.71 & \\
\hline Item 19 & & 0.44 & \\
\hline Item 20 & & 0.72 & \\
\hline Item 21 & & 0.68 & \\
\hline Item 11 & & & 0.36 \\
\hline Item 12 & & & 0.61 \\
\hline Item 13 & & & 0.67 \\
\hline Item 14 & & & 0.48 \\
\hline
\end{tabular}

Note: Extraction method: Principal component analysis; Rotation method: Varimax with Kaiser normalization rotation converged in 4 iterations.

\section{Discussion}

The analysis of the internal consistency of the WAMS showed different values for the three factors of the scale. The first factor, acceptance of women in key leadership positions, obtained a Cronbach's alpha of 0.79 ; the second factor, enterprise features for business success, a Cronbach's alpha of 0.77 ; and the third factor, specific barriers for access to a managerial post, of 0.34 . These data show coherence with previous research made by Cordano et al. [26] where the acceptance factor showed a Cronbach's alpha of 0.83; the features factor, 0.75; and the barriers factor a Cronbach's alpha of 0.46 .

Furthermore, in this study, analysis of the internal consistency of the full scale including the 21 items displayed a Cronbach's alpha coefficient of 0.75 . This fact shows consistency with the work made by Terbor et al. [24], which emphasized the use of scale globally and not divided by factors. This same proposal is also accepted by authors like Crino et al. [25] or Cordano et al. [26]. In both works, the instability of the factors within the different population samples is highlighted. Such instability results in greater acceptance of the use of the scale using unidimensionality.

Along this line, the factor exploratory analysis conducted in this study to explore the construct validity of the WAMS resulted in obtaining the aforementioned three factors that together explain the $40.66 \%$ variance. The factor characteristics explain the $25.64 \%$ variance, factor acceptance $8.88 \%$, and barriers a $6.15 \%$ variance factor. Additionally, the factorial analysis does not use the theoretical scale structure since factor features grouped three items of the barrier factor and the acceptance factor had an item of factor barriers. These data agree with the study of Cordano et al. [26], which explained that the WAMS is multidimensional, but not concerning the 21 items since only the items corresponding to the acceptance factor and the factor features should be used without changes or refinement (there is a need for improvement in future studies). The factor related to barriers could produce a strong factor, but further analysis and development of new items that have relevant relationships with the original items is needed. 
Although it accepted that the WAMS can have some limitations corrected, this instrument has a wide scientific background in studies from numerous fields of knowledge such as in Schein [30], where research that showed that men in middle management positions obtained more success by having typical characteristics of men, concluding that stereotypes tend to reduce the opportunities for women to advance in their companies. In addition, the study of Dubno [31] concluded that women had negative attitudes such as the Queen Bee syndrome toward other women executives. This same situation was also observed in several countries, for example, in Mexico [32], the United States and Chile [33], and India [34].

\section{Conclusions}

The Women As Managers Scale (WAMS) is one of the most internationally used scales in the literature. This work presents a Spanish version of WAMS for the sports industry. The WAMS offers adequate properties, offering a three-factor model. However, some problems of the instrument should be considered when applying the instrument since the sub-scale 'barriers' do not have the desired consistency. Hence, the sub-scale 'barriers' should be interpreted cautiously. In this regard, the instrument allows a simple and fast exploration of the acceptance of the target sample toward women as managers. The validation of the WAMS in the Spanish context among sport managers helps to reflect the degree to which current society accepts women equally in sport management.

All these data are fundamental for addressing the remaining gender gap in sports managerial positions. Sport managers could benefit from this scale and implement best practices for closing the existing gap. Additionally, this work contributes to implementing better policies in the sports sector to favor equally among both genders. Therefore, policymakers also could benefit from this work.

This study, despite having useful findings, suffers from several limitations. Any research that is conducted in restricted geographical boundaries may have certain limitations that render generalizing the findings across the borders or even within the regions of the same country, difficult. First, it could be interesting to study a cross-cultural sample in order to check and compare the state of the glass ceiling in different regions worldwide. Second, a limitation also pertains to the collection of data from the sports field. Third, the third factor analyzed of specific barriers for access to managerial positions did not have the desired validity.

Further research could also explore the glass ceiling phenomenon related to minorities. Selection and promotion criteria and the personal attributes of males and females can also be studied for in-depth analysis. The impact of policies and special laws as well as their implementations can also be cross-validated in future research to resist the glass ceiling.

Author Contributions: Conceptualization, J.G.-P.; Methodology, J.G.-P. and J.L.-Q.; Validation, J.G.P.; Formal analysis, J.G.-P. and B.R.-M.; Data curation, J.G.-P. and V.P.-H.; Writing—original draft preparation, J.G.-P.; Writing — review and editing, J.G.-P., B.R.-M., V.P.-H., and J.L.-Q.; Supervision, J.G.-P. and J.L.-Q. All authors have read and agreed to the published version of the manuscript.

Funding: This research received no external funding.

Institutional Review Board Statement: Ethical review and approval were waived for this study, due to the non-interventional and non-invasive design. No medical research involving human subjects was performed.

Informed Consent Statement: Informed consent was obtained from all subjects involved in the study.

Data Availability Statement: The data presented in this study are available on request from the corresponding author. The data are not publicly available due to confidentiality reasons.

Conflicts of Interest: The authors declare no conflict of interest. 


\section{Appendix A}

\section{Spanish WAMS}

1. Es menos deseable para las mujeres que para los hombres tener un trabajo que requiera responsabilidad.

2. Las mujeres tienen la objetividad requerida para evaluar convenientemente situaciones de negocio.

3. Los retos en el trabajo son más importante para los hombres que para las mujeres.

4. Los hombres y las mujeres deben contar con las mismas oportunidades de participar en los programas de formación para directivos.

5. Las mujeres tienen la capacidad de adquirir las habilidades necesarias para ser directivas de éxito.

6. En promedio, las mujeres directivas son menos capaces que los hombres de contribuir a los objetivos globales de una organización.

7. No es aceptable para la mujer asumir roles de liderazgo, tan a menudo como los hombres.

8. El mundo de los negocios debería aceptar algún día a mujeres en puestos directivos clave.

9. La sociedad debe considerar el trabajo de mujeres directivas tan valioso como el trabajo de hombres directivos.

10. Es aceptable para la mujer competir con hombres para alcanzar puestos de alta dirección.

11. La posibilidad de embarazo no hace empleadas menos deseables a las mujeres que a los hombres.

12. Las mujeres no deberían permitir que sus emociones influyan en su comportamiento como directivas más que a los hombres.

13. Los problemas asociados con la menstruación no deberían hacer a las mujeres menos deseables como empleadas que a los hombres.

14. Para ser un ejecutivo de éxito, una mujer no debe sacrificar nada de su feminidad.

15. En promedio, una mujer que está en casa todo el tiempo con sus hijos es una madre mejor que una mujer que trabaja fuera del hogar al menos media jornada.

16. Las mujeres son menos capaces de aprender habilidades matemáticas y mecánicas que los hombres.

17. Las mujeres no son los suficientemente ambiciosas como para triunfar en el mundo de los negocios.

18. Las mujeres no pueden ser enérgicas en las situaciones de negocio que lo demandan.

19. Las mujeres poseen la confianza en sí mismas requerida para ser una buena líder.

20. Las mujeres no son lo suficientemente competitivas como para triunfar en el mundo de los negocios.

21. Las mujeres no pueden ser agresivas en las situaciones de negocios que lo demandan.

\section{References}

1. Selva, C.; Sahagún, M.Á.; Pallarès, S. Estudios sobre trayectoria profesional y acceso de la mujer a cargos directivos: Un análisis bibliométrico. Rev. Psicol. Trab. Organ. 2011, 27, 227-242.

2. Burton, L.J. Underrepresentation of women in sport leadership: A review of research. Sport Manag. Rev. 2015, 18, 155-165. [CrossRef]

3. The Wall Street Journal. The Phrase 'Glass Ceiling' Stretches Back Decades. Available online: https://www.wsj.com/articles/thephrase-glass-ceiling-stretches-back-decades-1428089010 (accessed on 8 April 2021).

4. Townsend, B. Breaking Through: The Glass Ceiling Revisited. Equal Oppor. Int. 1997, 16, 4-13. [CrossRef]

5. Johns, M.L. Breaking the glass ceiling: Structural, cultural, and organizational barriers preventing women from achieving senior and executive positions. Perspect. Health Inf. Manag. 2013, 10, 1-11.

6. Hoyt, C.L. Women and leadership. In Leadership: Theory and Practice; Northouse, P., Ed.; SAGE Publications: Thousand Oaks, CA, USA, 2007; pp. 265-299.

7. Carlson, B.A. Mujeres en la Estadística: La Profesión Habla; United Nations: Santiago, Chile, 2000.

8. López-Ibor, R.; Escot, L.; Fernández, J.A.; Mateos, R. Análisis de la Presencia de las Mujeres en los Puestos Directivos de las Empresas Madrileñas; Biblioteca Nueva: Madrid, Spain, 2008.

9. Martínez del Castillo, J.; Navarro, C.; Fraile, A.; Puig, N.; Jiménez, J.; de Miguel, C. Deporte, Sociedad y Empleo. Proyección del Mercado Deportivo Laboral en la España de los Noventa. En los Sectores de Entrenamiento, Docencia, Animación y Dirección; Ministerio de Educación y Ciencia, Consejo Superior de Deportes: Madrid, Spain, 1992.

10. Spanish Statistical Office Encuesta de Población Activa. 2020. Available online: https://www.ine.es/dyngs/INEbase/es/ operacion.htm?c=Estadistica_C\&cid=1254736176918\&menu=ultiDatos\&idp=1254735976595 (accessed on 24 February 2021).

11. Institute of Women Mujeres en Cifras. Available online: https:/ /www.inmujer.gob.es/MujerCifras/Home.htm (accessed on 24 February 2021). 
12. del Mar Alonso-Almeida, M.; Perramon, J.; Bagur, L. Women managers and corporate social responsibility (CSR) in Spain: Perceptions and drivers. Women's Stud. Int. Forum 2015, 50, 47-56. [CrossRef]

13. European Institute for Gender Equality Gender Equality Index. Index Sccore for Spain for the 2020 Edition. Available online: https: / / eige.europa.eu/gender-equality-index/2020/country/ES (accessed on 24 February 2021).

14. European Union and Council of Europe. All in: Towards Gender Balance in Sport. Available online: https://www.coe.int/en/ web/human-rights-channel/all-in/\# (accessed on 8 April 2021).

15. Consejo Superior de Deportes (CSD). Datos Estadísticos de las Memorias Anuales Sobre Diferentes Aspectos del Deporte Federado y de Alta Competición. 2019. Available online: https://www.csd.gob.es/es/federaciones-y-asociaciones/federacionesdeportivas-espanolas/otras-estadisticas (accessed on 8 April 2021).

16. Heilman, M.E. How gender stereotypes prevent women's ascent up the organizational Ladder. J. Soc. Issues 2001, 57, 654-657. [CrossRef]

17. Gender Advisory Council Closing the Gender Gap: Challenges, Opportunities and the Future. Available online: https://www. pwc.com/gx/en/women-at-pwc/assets/closing_the_gender_gap_full_film_transcript.pdf (accessed on 24 February 2021).

18. Pratto, F.; Stallworth, L.M.; Sidanius, J.; Siers, B. The gender gap in occupational role attainment: A social dominance approach. J. Pers. Soc. Psychol. 1997, 72, 37-53. [CrossRef]

19. Yavuzer, Y.; Özkar, R. Akademisyenler Için Cam Tavan Engelleri Ölçeği: Geçerlik Ve Güveni;rlik Çalişmasi [Glass Ceiling Barriers Scale for Academicians: Validity and Reliability Study]. Univ. J. Soc. Sci. Inst. 2020, 40, 585-599.

20. Salsabila, F.; Munawir, Y.; Fadjri, K.A. Gender Stereotypes and Self-Efficacy as Determinants of the Glass Ceiling Effect: A Study of Female Civil Servants in Central Java. J. Psikologi. 2020, 47, 56-63.

21. Karaca, A. Kadın Yöneticilerde Kariyer Engelleri: Cam Tavan Sendromu Üzerine Uygulamalı bir Araştırma [Career Barriers for Female Managers: An Applied Research on Glass Ceiling Sindrome]. Master's Thesis, Selçuk University, Konya, Turkey, 2007.

22. Valentine, S. Development of a brief multidimensional aversion to women who work scale. Sex Roles 2001, 44, 773-787. [CrossRef]

23. Peters, L.H.; Terborg, J.R.; Taynor, J. Women as managers scale: A measure of attitudes toward women in management positions. Jsas Cat. Sel. Doc. Psychol. 1974, 4, 27.

24. Terborg, J.R.; Peters, L.H.; Ilgen, D.R.; Smith, F. Organizational and Personal Correlates of Attitudes Toward Women as Managers. Acad. Manag. J. 1977, 20, 89-100.

25. Crino, M.D.; White, M.D.; DeSanctis, G.L. A Comment on the Dimensionality and Reliability of the Women As Manager Scale (Wams). Acad. Manag. J. 1981, 24, 866-876.

26. Cordano, M.; Scherer, R.; Owen, C. Dimensionality of the Women as Managers Scale: Factor Congruency Among Three Samples. J. Soc. Psychol. 2003, 143, 141-143. [CrossRef] [PubMed]

27. Consejo Superior de Deportes (CSD). Censo de Instalaciones Deportivas de la Comunidad de Madrid; Ministry of Culture and Sport: Madrid, Spain, 2005; Available online: http:/ /www.csd.gob.es/csd/instalaciones/politicas-publicas-de-ordenacion/ 1CenInstDep/ (accessed on 24 February 2021).

28. Cea D'Ancona, M.A. Métodos de Encuesta. Teoría y Práctica, Errores y Mejora; Editorial Síntesis: Madrid, Spain, 2005.

29. López-Pintor, R.; Wert, J.I. El análisis de los datos de encuesta. In El Análisis de la Realidad Social: Métodos y Técnicas de Investigación; Ibáñez, J., García-Ferrando, M., Eds.; Alianza Editorial: Madrid, Spain, 2015; pp. 525-554.

30. Schein, V.E. Relationships between sex role stereotypes and requisite management characteristics among female managers. J. Appl. Psychol. 1975, 60, 340-344. [CrossRef] [PubMed]

31. Dubno, P. Attitudes Toward Women Executives: A Longitudinal Approach. Acad. Manag. J. 1985, 28, $235-239$.

32. Muller, H.J.; Rowell, M. Mexican women managers: An emerging profile. Hum. Resour. Manage. 1997, 36, 423-435. [CrossRef]

33. Cordano, M.; Scherer, R.F.; Owen, C.L. Attitudes toward women as managers: Sex versus culture. Women Manag. Rev. 2002, 17, 51-60. [CrossRef]

34. Gulhati, K. Attitudes toward Women Managers: Comparison of Attitudes of Male and Female Managers in India. Econ. Polit. Wkly. 1990, 25, 18-41. 